\title{
Vaginal ecology in Cameroonian urban areas: study of the flora of douala city inhabitants
}

\begin{abstract}
Introduction: The vaginal flora consists of bacilli of Doderleïn (various species of lactobacilli) which constitute a biofilm on the mucosa. These bacteria play a protective role by inhibiting the growth, adhesion or expansion of other microorganisms. To do this, various mechanisms are deployed, including the secretion of organic acids, antimicrobial substances, competition for nutrients and receptor sites as well as steric exclusion.
\end{abstract}

This balance is sometimes called into question by the use of oral medications and antiseptics for vaginal cleansing, oral contraception, diseases such as the Human Immunodeficiency Virus (HIV) or diabetes.

Objective: The objective of this work was to study the vaginal flora of women residing in the city of Douala.

Methodology: we carried out in three health structures in the city of Douala a transverse analytical study for seven (7) months in women aged at least 21 years. We randomly included 540 women who gave their written and signed consent. The variables of interest were sociodemographic, clinical and microbiological variables. Gram staining was used and read using an optical microscope for the identification of microorganisms and the classification of flora consisting of bacteria from vaginal secretions. The statistical tests used for the comparison of the numbers were chi-square and the exact fisher test with a significance threshold of $5 \%(\mathrm{p}<0.05)$

Results: A total of five hundred and forty (540) women had their samples collected. The majority age group was that of 30-40 years with $28.30 \%$ of cases. The mean age was 42.58 years $(+/-13.37)$. Four types of vaginal flora have been identified, in particular Type 4 (complete disappearance of the Döderlein flora with the appearance of abundant, polymorphic replacement flora and presence of clues-cells) with $36.30 \%$ of cases; Type 3 (rare, minority lacto-bacillary flora with the appearance of a substitution flora with a dominant morphology) at 32.20\%; Type 1 (mainly Döderlein flora: lactobacilli) at 17.20\%; Type 2 (Döderlein flora present and predominant but with a substitution flora without dominant morphology) at $14.30 \%$. The factors associated with the flora imbalance
Volume II Issue 3 - 2020

\author{
Essome Henri, ${ }^{1,2}$ Ebongue Cécile,' Egbe \\ Obinchemti Thomas, ${ }^{3}$ Halle Ekane Gregory, ${ }^{3}$ \\ Nida Martine Colette,' Boten Merlin, ${ }^{2}$ Tocki \\ Toutou Grâce, ${ }^{2}$ Foumane Pascal, ${ }^{4}$ Adiogo \\ Dieudonné,' Mboudou Emile Télesphore ${ }^{4}$ \\ 'Faculty of Medicine and Pharmaceutical Sciences of Douala, \\ University of Douala, Cameroon \\ 2Laquintinie hospital in Douala, Cameroon \\ ${ }^{3}$ Faculty of health sciences of Buea, University of Buea, \\ Cameroon \\ ${ }^{4}$ Faculty of medicine and biomedical sciences of Yaoundé, \\ University of Yaoundé I, Cameroon
}

Correspondence: Essome Henri, Faculty of Medicine and Pharmaceutical Sciences of Douala, University of Douala, Cameroon, Tel +237696475672 Email essometocky@yahoo.com

Received: May 12, 2020 | Published: May 25, 2020

were scented soaps $(\mathrm{OR}=1.84 ; 95 \% \mathrm{CI}=1.77-2.73 ; \mathrm{P}=0.001)$, antiseptic products $(\mathrm{OR}=2.04 ; 95 \% \mathrm{CI}=1,05-5.67 ; \mathrm{P}=0.004)$ and the risk increased by combining them $(\mathrm{OR}=4.04 ; 95 \% \mathrm{CI}=3.92-6.49 ; \mathrm{P}=0.001) 95 \% \mathrm{CI}=1.77$ 2.73; $\mathrm{P}=0.001$ ), Oral contraception, $\mathrm{HIV}$ infection and diabetes also altered the flora. In addition, the presence of yeasts and mycelial filaments also favoured the degradation of the flora. On the other hand, drinking water appeared as a protective factor $(\mathrm{OR}=0.19 ; 95 \% \mathrm{CI}=0.043-0.84 ; \mathrm{P}=0.028)$.

Conclusion: the vaginal flora of women residing in Douala is mainly degraded in a cumulative percentage of $68.50 \%$ and represented by types 4 and 3.

Keywords: vaginal flora, lactobacilli, Type 4 and 3 imbalances

washing, contraception, diseases like HIV or diabetes. ${ }^{2}$ A study carried out in 2011 on the composition of the vaginal ecosystem of 396 women from four different origins (Asian, Caucasian, Black, Hispanic), using molecular methods demonstrated that the bacterial communities dominated by lactobacilli are mainly found in women of Asian origin (80.2\%) and Caucasian (89.7\%). Anaerobic bacteria were mainly found in black (40.6\%) and Hispanic (38.1\%) women. ${ }^{3}$

In the United States, the imbalance of the vaginal flora (VF) was present in 33 to $36 \%$ of patients coming from the departments of sexually transmitted infections (STI) and affected more than $25 \%$ of patients consulting in gynaecological clinics. ${ }^{4,5}$

Whereas in sub-Saharan Africa and precisely in Uganda, the imbalance of VF affected $20 \%$ to $50 \%$ of women. ${ }^{6}$ In Malawi, among 9,148 women in an urban population, only $11 \%$ had normal flora, $30 \%$ of women had bacterial vaginosis (BV) flora and 59\% had slightly disturbed flora. ${ }^{?}$

In the Cameroonian context, no study has been interested in the into question by the use of oral antibiotic drugs and antiseptics for 
problem of the constitution of VF, which is however essential for the health of women. This is the rationale for this study.

\section{Materials and methods}

\section{Type of study, place, period and duration}

It was a cross-sectional analytical study with prospective data collection conducted for 07 months (from November 1, 2017 to June 25,2018 ) in three hospitals at the top of the health pyramid of Cameroon; namely the general hospital of Douala (GHD) the gynaeco-obstetrics and paediatric hospital of Douala (GOPH), the Laquintinie hospital of Douala (LHD).

\section{Study population}

The study population consisted of women residing in the districts of the city of Douala received in gynaecological consultation or received in the various laboratories of the GHD, GOPH and the LHD.

\section{Inclusion and exclusion criteria}

Were included those who were sexually active at least 21 years of age consenting and residing in Douala and excluded the nonconsenting, the virgins, the pregnant and those who were menstruating.

\section{Sampling}

The sampling was consecutive non-probabilistic with a basic sample size set at 384 according to the Lorentz formula.

$$
\mathrm{n}=(\mathrm{z}) 2 \cdot \mathrm{p}(1-\mathrm{p}) / \mathrm{d} 2
$$

n: sample size for obtaining significant results for an event and a fixed risk level

$\mathrm{z}$ : confidence level according to the reduced centred normal law (for a confidence level of confidence of $95 \%, z=1.96$ for a confidence level of $99 \%, z=2.575$ )

$\mathrm{p}$ : estimated proportion of the population with the characteristic (when $\mathrm{p}$ unknown, we use $\mathrm{p}=0.5$ )

d: margin of error (generally set at 5\%)

We have taken $\mathrm{z}=1.96$ and $\mathrm{p}=0.5$ because unknown

$$
\begin{aligned}
& \mathrm{n}=(1.96) 2 \times 0.5(1-0.5) /(0.05) 2 \\
& \mathrm{n}=(3.8416 \times 0.25) / 0.0025 \\
& \mathrm{n}=384.16
\end{aligned}
$$

Before their inclusion in the study, the women all received and read an information sheet on the purpose of the study as well as its progress, its safety and the confidentiality of the information to be collected. Following which they freely signed two copies of an informed consent attesting to their participation agreement. A copy of the consent was then given to them. The inclusion was done randomly according to the order of presentation either in the laboratory or in consultation.

The data were collected by interrogation and recorded on a pretested survey form in the form of a questionnaire.

The variables of interest were;

A. Socio-demographic age, level of education, profession; the neighbourhood of residence; - Gynaecological and obstetric: sexual practices (age at first intercourse, number of sexual partners, protected or unprotected intercourse); Number of pregnancies; number of deliveries; date of the last period; cycle length; date of last gynaecological consultation; anterior cervico-vaginal sample; previous vaginal infection (chlamydia, mycoplasma, syphilis, herpes simplex 2, gonococcal disease) products used for intimate hygiene (perfumed toilet soap, intimate gel, antiseptic products, simple water); taking tobacco.

B. Clinics (patient under radiotherapy or chemotherapy-antibioticsantiretrovirals-corticoids; Human Immunodeficiency Virus (HIV), diabetes, hypertension, concept of pain, bleeding, pruritus).

C. Microbiological typing of flora, isolation of pathogenic germs.

i. After a woman was called, she took off her underwear and sat on a gynaecological examination table, followed by the placement of a speculum.

ii. A cervico-vaginal sample using a swab from the vaginal wall and Douglas pouch was performed in women aged at least 21 years, and then a macroscopic examination describing the appearance, the colour and the amount of leukorrhea was done.

iii. A fine spreading of each sample was carried out on previously identified glass slides to avoid any confusion; then dried to avoid destroying the smears.

iv. The slides were stored in their original boxes one after the other and separated with paper to prevent them from coming into contact and then kept away from humidity and dust. Untreated swabs were stored at room temperature $15-25^{\circ}$ for $2 \mathrm{~h}$ or in a refrigerator $2-8^{\circ}$ for $48 \mathrm{~h}$.

Reading of samples was performed with an optical microscope of OPTIKA brand, lot NO: 430117.

\section{Procedures}

Administrative procedures: We requested and obtained an ethical clearance from the institutional ethics committee of the University of Douala as well as a research authorization from the Director of the GHD, the Director of the GOPH, the Director of the LHD.

\section{Analytical phase}

Gram staining: Gram staining was carried out using gentian violet, lugol, methanol and fushin/safranin: we covered the slides with violet crystal solution, after 1 minute we washed them gently with water. Then we covered them with the stabilized lugol complex which played the role of biting to improve the fixation of gentian violet, after 1 minute we washed them gently with water. After using methanol, they were discoloured for 10 seconds and then washed directly with water to stop the discoloration. Finally, the slides were covered with fushin solution for counter staining, after 1 minute we washed them gently with water.

\section{Reading the Gram}

The Gram was read under the light microscope to assess the vaginal flora. We put a drop of immersion oil on each slide, then we observed each slide at objective 100. The clinical and cytobacteriological aspects allowed us to describe the ecology of the vaginal flora.

This review allowed us to classify VF into four types: 
a. Flora type I: Döderlein flora (lactobacilli) mainly

b. Flora type II: Döderlein flora is present and predominant but there is a substitution flora without dominant morphology

c. Flora type III: The lacto-bacillary flora is rare, a minority with the appearance of a substitution flora with a dominant morphology. d. Flora type IV: Complete disappearance of the Döderlein flora with the appearance of an abundant, polymorphic substitution flora and presence of clues-cells.

We detected the presence of yeasts or mycelial filaments and leukocytes.

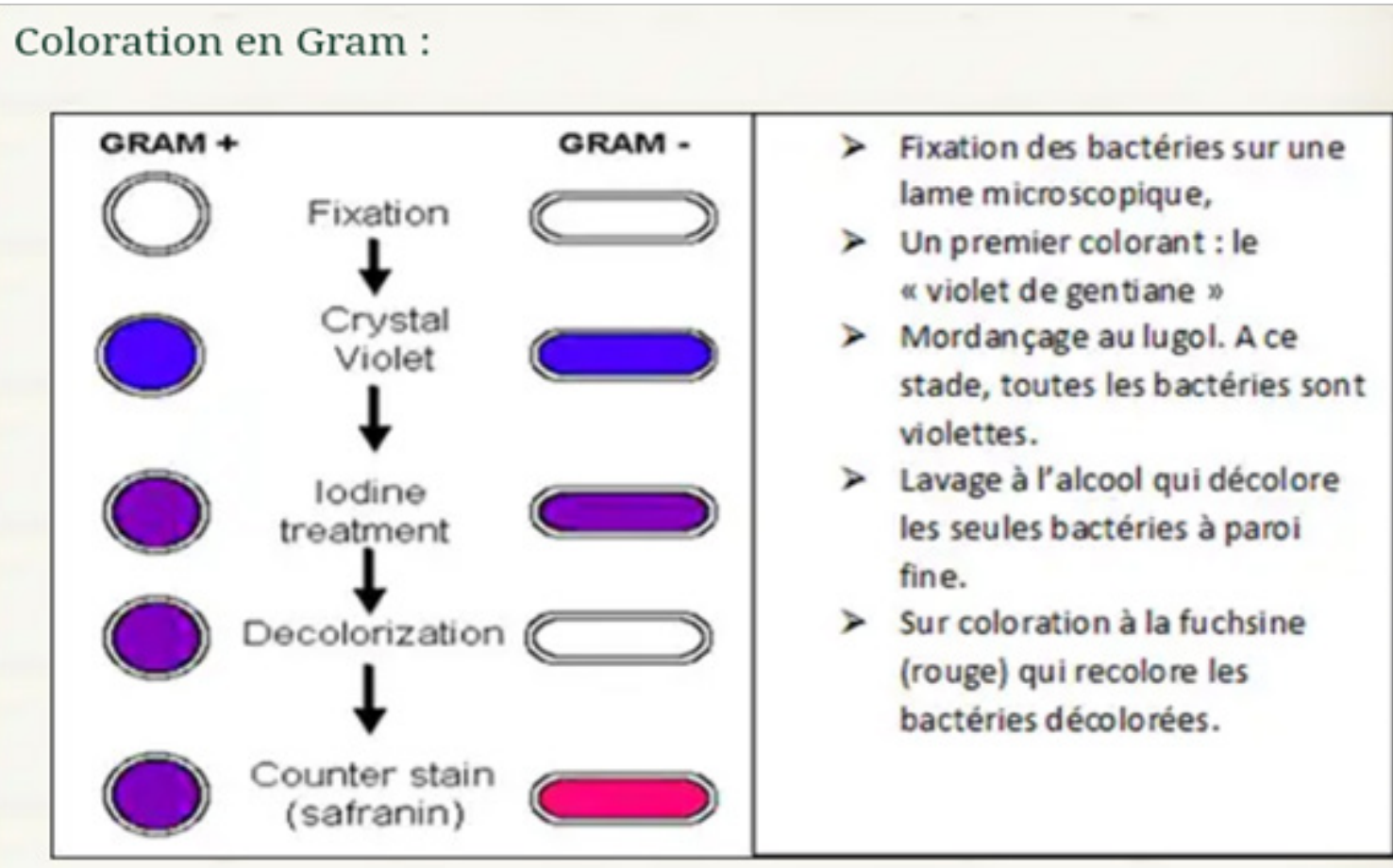

Figure I Steps in gram staining.

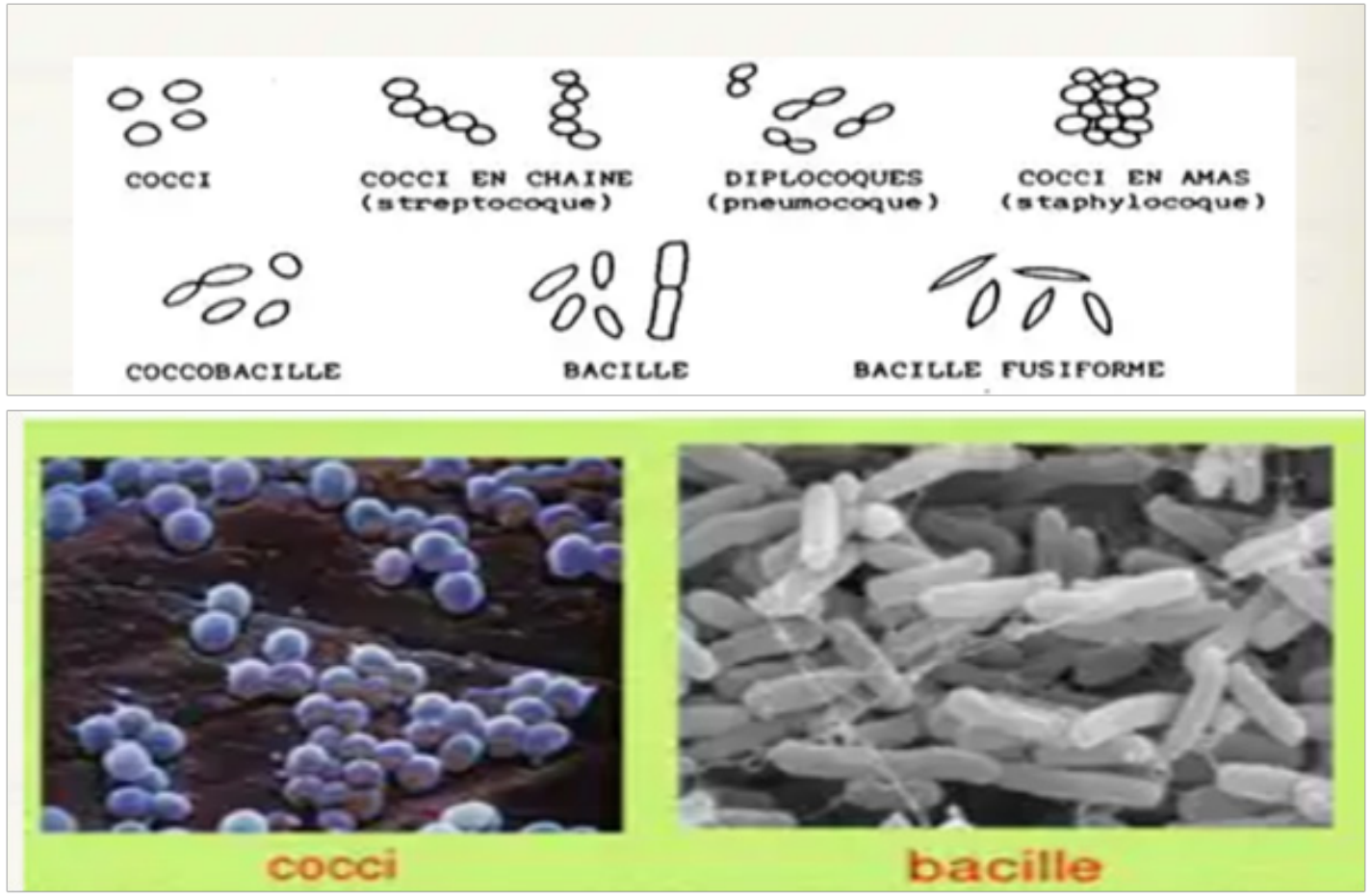

Figure 2 Shell forms (coccus, cocci in the plural), elongated forms in rods or bacilli, intermediate forms or coccobacilli.

Citation: Henri E, Cécile E, Thomas EO, et al.Vaginal ecology in Cameroonian urban areas: study of the flora of douala city inhabitants. Obstet Gynecol Int J. 2020; I (3): 169-177. DOI: I0.15406/ogij.2020.I I.00505 
We observed round or shell forms (coccus, cocci in the plural), elongated forms in rods or bacilli, intermediate forms or coccobacilli (Figure 2). After Gram staining, the thick-walled bacteria were coloured purple: and said "Gram positive", the thin-walled bacteria were coloured red or pink and said "Gram negative".

\section{Results}

During our study which took place from January 1, 2017 to June 25, 2018, we received 596 women, sampled 540 and excluded 56 women including 7 virgin women, 22 pregnant women and 27 women because of menstruation.

\section{Sociodemographic data}

The average age and the median of our population were 42.58 years and 41 years respectively, with a standard deviation of 13.37 and the extremes of 21 and 77 years. The majority age group was that of [30-40] with $28.3 \%$ of cases (Table 1).

Table I Distribution of the population according to age

\begin{tabular}{lll}
\hline Age & Number $\mathbf{N}$ & Percentage \% \\
\hline$[21-30]$ & 96 & 17,8 \\
{$[30-40]$} & 153 & 28,3 \\
{$[40-50]$} & 125 & 23,1 \\
{$[50-60]$} & 93 & 17,2 \\
{$[60-70]$} & 57 & 10,6 \\
$\geq 70$ & 16 & 3,0 \\
Total & 540 & 100 \\
\hline
\end{tabular}

Concerning the profession, more than half of our population was made up of housewives with a percentage of $52.4 \%$. The majority level of education was secondary school with $40 \%$. More than half of our sample consisted of married women with $56.3 \%$ of the cases. The obstetric history was dominated respectively by the large multipara with $25.7 \%$ and the pauciparous with $28.0 \% ; 33.88 \%$ (183cases) of our sample had a history of sexually transmitted infection (Table 2).

\section{Clinical data}

Pruritus was the most reported clinical sign by the respondents with a percentage of $25.2 \%$ (Figure 3 ).

\section{Biological data}

The vaginal flora was mainly of types 4 and 3 with respectively $36.3 \%$ and $32.1 \%$ (Figure 4 ).

Distribution of type of flora by age: The flora of types 1 and 2 were mainly and significantly found in the age group of $[30-40]\left(x^{2}=55.1\right.$ $\mathrm{P}=0.00$ ) while the flora of types 3 and 4 mainly affected the age groups [50-60] and [40-50] with a significant statistical difference for the [50$60]\left(\mathrm{x}^{2}=62,2(\mathrm{P}=0.00)\right.$ and not significant for the $[40-50]\left(\mathrm{x}^{2}=13.8\right)$ $(\mathrm{P}=0.13)$ (Table 3).

Distribution of the type of flora by profession: Workers in the public and informal sectors were predominantly and significantly carriers of type 1 and 2 floras $\left(\mathrm{x}^{2}=23.1\right)(\mathrm{P}=0.01$ for the public sector); $\left(\mathrm{x}^{2}=17.5\right)(\mathrm{P}=0.04$ for the informal sector).However, flora types 3 and 4 were particularly predominant among housewives with, however, a non-significant difference $\left(\mathrm{x}^{2}=12.1 \mathrm{P}=0,21\right)$ (Table 4).
Distribution of the type of flora according to the level of education: Flora types 1 and 2 were significantly present in women at the university level $\left(\mathrm{x}^{2}=57 \mathrm{P}=0.00\right)$. Whereas Types 3 and 4 were not among secondary school women who made the majority $\left(\mathrm{x}^{2}=14.5\right.$ $\mathrm{P}=0.11$ ) (Table 5).

Table 2 Distribution of the population according to occupation, level of education, marital status, gravidity, parity and history of genital infection

\begin{tabular}{|c|c|c|c|}
\hline Variables & & $\begin{array}{l}\text { Number } \\
\mathbf{N}\end{array}$ & $\begin{array}{l}\text { Percentage } \\
\%\end{array}$ \\
\hline \multirow{7}{*}{ Occupation } & Housewife & 283 & 52,4 \\
\hline & Autoemployed & 5 & 0,9 \\
\hline & unemployed & 42 & 7,8 \\
\hline & & & \\
\hline & Informal sector & 100 & 18,5 \\
\hline & privatesector & 56 & 10,4 \\
\hline & Publicsector & 54 & 10,0 \\
\hline \multirow{5}{*}{ Level of education } & Uneducated & 70 & 13,0 \\
\hline & Primary & 92 & 17,0 \\
\hline & & & \\
\hline & Secondary & 216 & 40,0 \\
\hline & University & 162 & 30,0 \\
\hline \multirow{3}{*}{ Maritalstatus } & Married & 304 & 56,3 \\
\hline & Single & 190 & 35,2 \\
\hline & Widow(er) & 46 & 8,5 \\
\hline \multirow{5}{*}{ Gravidity } & Nulligravid (0) & 85 & 15,7 \\
\hline & Primigravid(I) & 55 & 10,2 \\
\hline & Paucigravid (2 à 3) & 125 & 23,1 \\
\hline & Multigravid(4 à 5) & 136 & 25,2 \\
\hline & $\begin{array}{l}\text { Grand Multigravid } \\
(>5)\end{array}$ & 139 & 25,7 \\
\hline \multirow{5}{*}{ Parity } & Nulliparous (0) & 113 & 20,9 \\
\hline & Primiparous(I) & 86 & 15,9 \\
\hline & Pauciparous (2 à 3) & $15 \mid$ & 28,0 \\
\hline & Multiparous (4 à 5) & 117 & 21,7 \\
\hline & $\begin{array}{l}\text { Grand Multiparous } \\
(>5)\end{array}$ & 73 & 13,5 \\
\hline \multirow{5}{*}{$\begin{array}{l}\text { History of genital } \\
\text { infection }\end{array}$} & Chlamydia & 126 & 23,3 \\
\hline & Syphilis & 22 & 4,1 \\
\hline & Mycoplasma & 19 & 3,5 \\
\hline & Gonorrhoea & 8 & 1,5 \\
\hline & Herpes simplex 2 & 8 & 1,5 \\
\hline
\end{tabular}




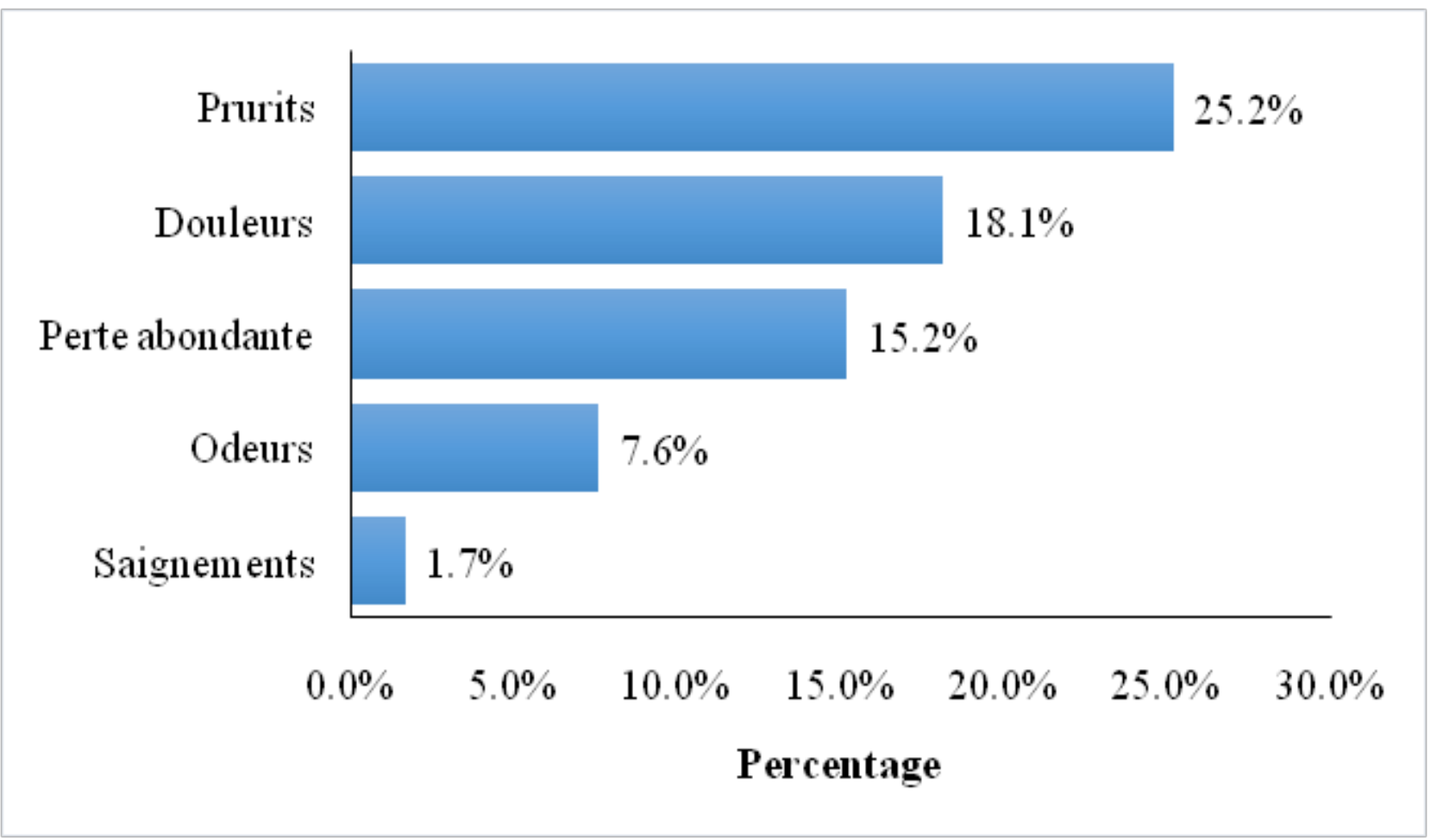

Figure 3 Distribution according to symptoms at the time of sample collection.

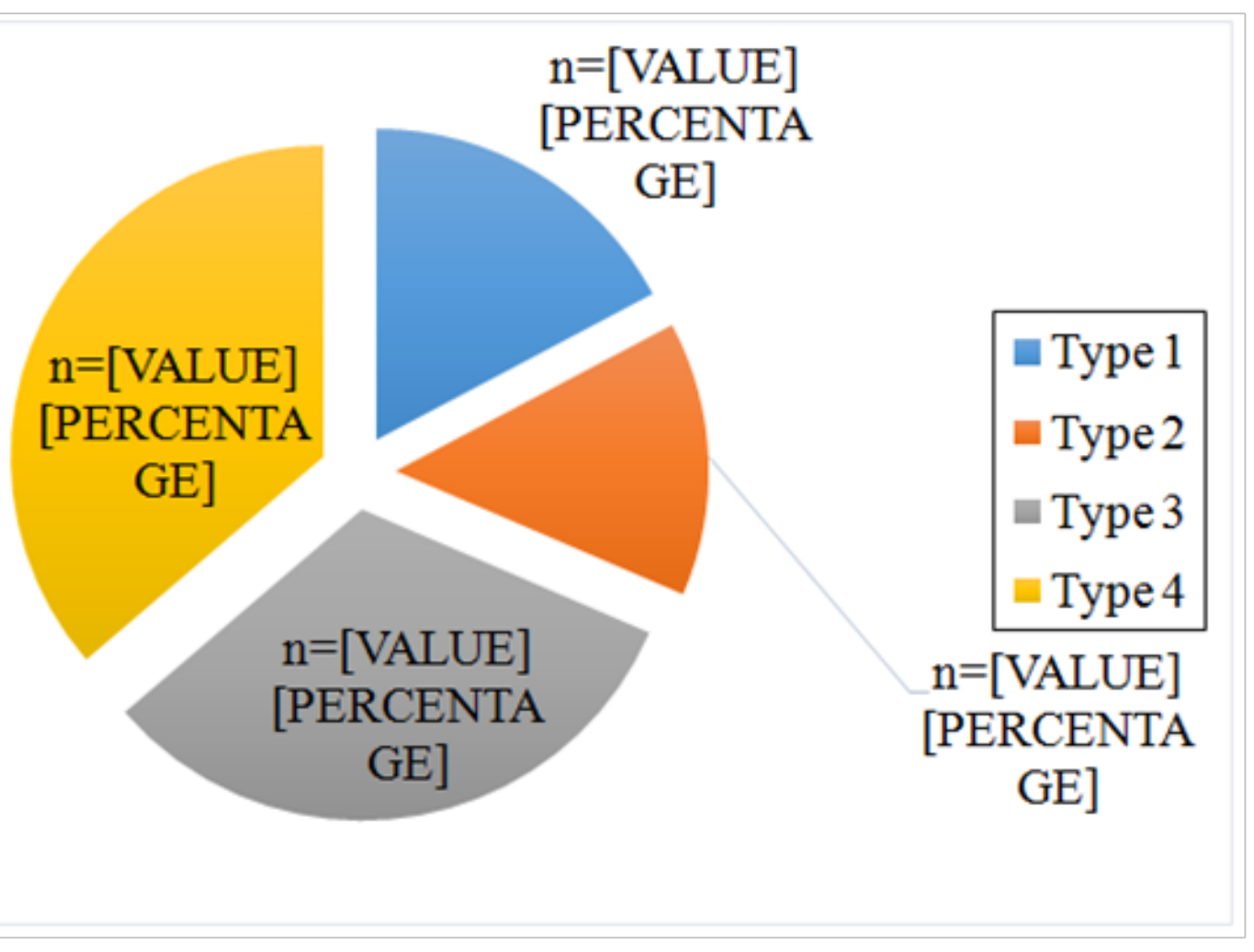

Figure 4 Distribution according to type of flora. 
Table 3 Distribution of type of flora according to age

\begin{tabular}{llllllllllll}
\hline \multirow{2}{*}{ Age } & \multicolumn{3}{l}{ Type I } & \multicolumn{2}{c}{ Type 2 } & \multicolumn{2}{c}{ Type 3 } & \multicolumn{2}{c}{ Type 4 } & \multirow{2}{*}{ P } \\
\cline { 2 - 9 } & $\mathbf{n}$ & $\mathbf{( \% )}$ & $\mathbf{n}$ & $\mathbf{( \% )}$ & $\mathbf{N}$ & $\mathbf{( \% )}$ & $\mathbf{N}$ & $\mathbf{( \% )}$ & & \\
\hline $21-30$ & 37 & $(40,2)$ & 20 & $(26,7)$ & 15 & $(8,5)$ & 24 & $(12,2)$ & 55,1 & 0,00 \\
$30-40$ & 38 & $(41,3)$ & 30 & $(40,0)$ & 38 & $(21,5)$ & 47 & $(24,0)$ & 22,7 & 0,01 \\
$40-50$ & 17 & $(18,5)$ & 25 & $(33,3)$ & 33 & $(18,6)$ & 50 & $(25,5)$ & 13,8 & 0,13 \\
$50-60$ & 0 & $(0,0)$ & 0 & $(0,0)$ & 59 & $(33,3)$ & 34 & $(17,3)$ & 62,2 & 0,00 \\
$60-70$ & 0 & $(0,0)$ & 0 & $(0,0)$ & 28 & $(15,8)$ & 29 & $(14,8)$ & 39,8 & 0,00 \\
$\geq 70$ & 0 & $(0,0)$ & 0 & $(0,0)$ & 4 & $(2,3)$ & 12 & $(6,1)$ & 22,4 & 0,01 \\
Total & 92 & $(100,0)$ & 75 & $(100,0)$ & 177 & $(100,0)$ & 196 & -100 & & \\
\hline
\end{tabular}

Table 4 Distribution of the type of flora according to occupation

\begin{tabular}{|c|c|c|c|c|c|c|c|c|c|c|}
\hline \multirow{2}{*}{ Occupation } & \multicolumn{2}{|c|}{ Type I } & \multicolumn{2}{|c|}{ Type 2} & \multicolumn{2}{|c|}{ Type 3} & \multicolumn{2}{|c|}{ Type 4} & \multirow{2}{*}{$x^{2}$} & \multirow{2}{*}{$\mathbf{P}$} \\
\hline & $n$ & (\%) & $\mathbf{n}$ & (\%) & $\mathbf{N}$ & (\%) & $\mathbf{N}$ & (\%) & & \\
\hline Housewife & 13 & $(14,0)$ & 13 & $(16,9)$ & 92 & $(52,9)$ & 108 & $(55, I)$ & $|2|$, & 0,21 \\
\hline Auto emplpoyed & 2 & $(2,2)$ & 0 & $(0,0)$ & 0 & $(0,0)$ & 3 & $(I, 5)$ & NC & NC \\
\hline Unemployed & 8 & $(8,6)$ & 4 & $(5,2)$ & 14 & $(8,0)$ & 20 & $(10,2)$ & 5,6 & 0,78 \\
\hline Informal sector & 19 & $(20,4)$ & 38 & $(49,4)$ & 45 & $(25,9)$ & 29 & $(14,8)$ & 17,5 & 0,04 \\
\hline Public sector & 45 & $(48,4)$ & 9 & $(I I, 7)$ & 8 & $(4,6)$ & 16 & $(8,2)$ & 23,1 & 0,01 \\
\hline Privatesector & 6 & $(6,5)$ & 13 & $(16,9)$ & 15 & $(8,6)$ & 20 & $(10,2)$ & 12,6 & 0,18 \\
\hline
\end{tabular}

Table 5 Distribution of the type of flora according to level of education

\begin{tabular}{|c|c|c|c|c|c|c|c|c|c|c|}
\hline \multirow{2}{*}{ Level of education } & \multicolumn{2}{|c|}{ Type I } & \multicolumn{2}{|c|}{ Type 2} & \multicolumn{2}{|c|}{ Type 3} & \multicolumn{2}{|c|}{ Type 4} & \multirow{2}{*}{$x^{2}$} & \multirow{2}{*}{$\mathbf{P}$} \\
\hline & $\mathbf{n}$ & (\%) & $\mathbf{n}$ & $(\%)$ & $\mathbf{N}$ & (\%) & $\mathbf{N}$ & $(\%)$ & & \\
\hline Uneducated & 9 & $(9,70)$ & 5 & $(6,50)$ & 18 & $(10,30)$ & 38 & $(19,40)$ & 20,5 & 0,02 \\
\hline Primary & 4 & $(4,30)$ & 6 & $(7,80)$ & 37 & $(21,30)$ & 45 & $(23,00)$ & 30,7 & 0,00 \\
\hline Secondary & 30 & $(32,30)$ & 27 & $(35,10)$ & 86 & $(49,40)$ & 73 & $(37,20)$ & 14,5 & 0,11 \\
\hline University & 50 & $(53,80)$ & 39 & $(50,60)$ & 33 & -19 & 40 & $(20,40)$ & 57,0 & 0,00 \\
\hline Total & 93 & -100 & 77 & -100 & 174 & -100 & 196 & -100 & & \\
\hline
\end{tabular}

Distribution of the results according to the germs encountered in Gram: The association of gram positive bacilli and gram-negative bacilli was predominant among the germs encountered $(50.9 \%)$ (Table 6).

Distribution according to the type of flora and the presence of yeasts: Yeasts and mycelial filaments were significantly absent in types 1 and 2 floras in our sample $\left(\mathrm{x}^{2}=15.3 \mathrm{P}=0.08\right)\left(\mathrm{x}^{2}=14.2 \mathrm{P}=0.07\right)$ and significantly present in flora type 3 and $4\left(x^{2}=10.1\right.$ and $\left.\mathrm{P}=0.03\right)$ (Table 7).

Distribution of the population according to the different risk factors: In the multivariate analysis, the use of scented soaps exposed significantly more than once to the imbalance of the flora
$(\mathrm{OR}=1.84 ; 95 \% \mathrm{CI}=1.77-2.73 ; \mathrm{P}=0.001)$, likewise that the use of antiseptic products which exposed them twice as much $(\mathrm{OR}=2.04$; $95 \% \mathrm{CI}=1.05-5.67 ; \mathrm{P}=0.004)$; the combined use of the two (perfumed soaps and antiseptic products) exposed them four times more to the imbalance of the flora $(\mathrm{OR}=4.04 ; 95 \% \mathrm{CI}=3.92-6.49 ; \mathrm{P}=0.001)$. Taking oral contraception exposed the flora imbalance more than once and significantly modified it $(\mathrm{OR}=1.69 ; 95 \% \mathrm{CI}=1.07-4.02 ; \mathrm{P}=0.023)$.

More than twice was HIV infection ( $\mathrm{OR}=2.26$; 95\% CI=1.87.14; $\mathrm{P}=0.001$ ) and almost four times was the risk of imbalance if the respondent was diabetic $(\mathrm{OR}=3.9 ; 95 \% \mathrm{CI}=1.05-4.01 ; \mathrm{P}=0.001)$. The use of drinking water during private toilets, on the other hand, appeared to be a protective factor in our study $(\mathrm{OR}=0.19 ; 95 \%$ $\mathrm{CI}=0.043-0.84 ; \mathrm{P}=0.028$ ) (Table 7). 
Table 6 Distribution of results according to germs encountered on gram stain

\begin{tabular}{lll}
\hline Germs & Number & Percentage \\
& N & $\%$ \\
\hline Lactobacilliand gram- bacilli & 275 & 50,9 \\
Gram-bacilli & 112 & 20,7 \\
Lactobacilli & 92 & 17,0 \\
Clues cells & 30 & 5,6 \\
Coccobacilliandgram- bacilli & II & 2,0 \\
Lactobacilli + Cocci + gram- bacilli & II & 1,9 \\
Mobiluncus & 10 & 1,9 \\
Total & 540 & 100
\end{tabular}

Table 7 Distribution of the population according to type of flora and quantity of yeast

\begin{tabular}{|c|c|c|c|c|c|c|c|c|c|c|c|}
\hline & & \multicolumn{2}{|c|}{ Type I } & \multicolumn{2}{|c|}{ Type 2} & \multicolumn{2}{|c|}{ Type 3} & \multicolumn{2}{|c|}{ Type 4} & \multirow{2}{*}{$x^{2}$} & \multirow{2}{*}{$\mathbf{P}$} \\
\hline & & $\mathbf{n}$ & (\%) & $\mathbf{n}$ & (\%) & $\mathbf{N}$ & (\%) & $\mathbf{n}$ & (\%) & & \\
\hline \multirow{6}{*}{ Yeast } & Absent & 63 & $(67,80)$ & 51 & $(66,30)$ & 13 & $(7,50)$ & 26 & $(13,30)$ & 15,3 & 0,08 \\
\hline & Numerous & 8 & $(8,60)$ & 8 & $(10,40)$ & 119 & $(68,40)$ & 119 & $(60,70)$ & 10,1 & 0,03 \\
\hline & Quitenumerous & 1 & $(I, I 0)$ & 0 & $(0,00)$ & 3 & $(1,70)$ & 5 & $(2,60)$ & 8,4 & 0,49 \\
\hline & Some & 5 & $(5,40)$ & 5 & $(6,50)$ & 18 & $(10,30)$ & 9 & $(4,60)$ & 12,6 & 0,18 \\
\hline & Rare & II & $(I I, 80)$ & 9 & $(1 \mathrm{I}, 70)$ & 16 & $(9,20)$ & 21 & $(10,70)$ & 4,0 & 0,91 \\
\hline & Very numerous & 5 & $(5,40)$ & 4 & $(5,20)$ & 5 & $(2,90)$ & 16 & $(8,20)$ & 12,3 & 0,20 \\
\hline \multirow{6}{*}{ Mycelian filaments } & Absent & 63 & $(67,80)$ & 53 & $(68,80 \%$ & 13 & $(7,50)$ & 24 & $(12,20)$ & 14,2 & 0,07 \\
\hline & Numerous & 12 & $(12,90)$ & 9 & $(\mathrm{I} I, 70 \%$ & 122 & $(70,10)$ & 126 & $(64,30)$ & 10,0 & 0,03 \\
\hline & Quitenumerous & I & $(1,10)$ & 2 & $(2,60 \%$ & 4 & $(2,30)$ & 1 & $(0,50)$ & 9,2 & 0,42 \\
\hline & Some & 6 & $(6,50)$ & 7 & $(9,10 \%$ & 15 & $(8,60)$ & 22 & $(1 \mathrm{I}, 20)$ & 15,7 & 0,07 \\
\hline & Rare & 8 & $(8,60)$ & 2 & $(2,60 \%$ & 16 & $(9,20)$ & 18 & $(9,20)$ & 12,1 & 0,21 \\
\hline & Very numerous & 3 & $(3,20)$ & 4 & $(5,20 \%$ & 4 & $(2,30)$ & 5 & $(2,60)$ & 33,6 & 0,00 \\
\hline
\end{tabular}

\section{Discussion}

\section{Limits of the study}

The limits of our study are essentially the declarative nature of certain variables and to a certain extent the sample size which in a mass study seems too fair for relevant conclusions.

\section{Epidemiological aspect}

The findings of Wanderley et al in Brazil ${ }^{9}$ are confirmed by our data; indeed,age groups [50-60]; [40-50] were the most affected by the imbalance of the vaginal flora with $33.3 \%$ for type 3 and $25.5 \%$ for type 4 .

Housewives were mostly affected in the order of $52.9 \%$ for type 3 and $55.1 \%$ for type 4 . Our results are largely above the $25 \%$ and $7.5 \%$ reported by Faye-Kette and al for housewives in Abidjan. ${ }^{10}$ The standard of living of the respondents could, in our opinion, be an explanatory path.

Although not significant, the flora imbalance mainly affected the women in secondary school in our sample in the order of $49.40 \%$ for type 3 and $37.2 \%$ for type 4 . Our findings seem to us to be superimposable on $38 \%$ d'Holzman et al in the United States. ${ }^{11}$

\section{Clinical data}

Pruritus was the functional sign mostly reported by our respondents in the order of $25.2 \%$ followed by pain $18.1 \%$ all similar to the work of Wanderley et al in Brazil where pruritus dominated with $24.67^{\circ} \%$, followed pain with $18.67 \%{ }^{9}$

\section{Biological data}

The biological collection of our study reveals a predominance of pathological flora in the order of $32.2 \%$ for type 3 and $36.3 \%$ for type 4. Our results are consistent with the data in the literature as reported by Silla et al in Senegal who found a predominance of types 3 and 4 in their study at the respective rates of at $33.5 \%$ and $36.2 \% .^{12}$

The results of the gram readings in our sample, although mostly represented by the association of lactobacilli and gram-negative bacilli, are heterogeneous compared to those of the literature. In fact, lactobacilli represented $17.2 \%$ of cases, lactobacilli associated 
with Gram negative bacilli 50.9\%, lactobacilli associated with cocci gram positive and gram-negative bacilli $2.0 \%$ of cases; clues cells were found in $5.6 \%$ of cases. These results are different from those of Mardh in France, where $28.6 \%$ of lactobacilli were represented, $7.1 \%$ of lactobacilli associated with gram negative bacilli, $17.9 \%$ of lactobacilli associated with cocci gram positive and gram-negative bacilli and $53,6 \%$ of clues cells. ${ }^{13}$ The high percentage of unbalanced flora as observed in our study may be the explanation.

\section{Risk factors}

Women who used scented soaps were twice as likely to have an imbalance in the vaginal flora as those who used plain water. These results are consistent with those of Oshida et al in India on their research on douching. ${ }^{14}$

Women who used antiseptic products alone were twice as likely to have an imbalance in the vaginal flora as women who used simple water. These results are similar to those of Juliano et al who had worked on douching. ${ }^{15}$

Women who had HIV were twice as likely to have an imbalance in the vaginal flora as women who did not have it. These results agree with those of de Bohbot et al in France on a study on vaginosis. ${ }^{8}$

Women with diabetes were 3 times more likely to have an imbalance in the vaginal flora than women who did not. These results are consistent with those of Goswami et al in a study on vaginal imbalances. ${ }^{16-20}$

\section{Conclusion}

At the end of our research, the aim of which was to study the ecology of the vaginal flora in women living in the city of Douala, it appears that:

a. The constitution of the vaginal flora of women residing in the city of Douala is similar to that of known literature and has not presented any specificities.

b. The imbalance of the vaginal flora is a frequent phenomenon among women in the city of Douala (32.2\% type 3; $36.3 \%$ type 4) and therefore remains a health problem.

c. The balance of the vaginal flora was disturbed by the use of antiseptic products, perfumed soaps, and contraceptive pills, diseases such as HIV or diabetes. The quantitative presence of yeasts also contributed to this imbalance.

\section{Contribution of our study to science}

Our study puts back under the scientific light the deleterious effect of vaginal douches as well as their inputs on the vaginal flora.

\section{Contribution of authors}

i. Essome designed the study, collected the data and wrote the manuscript

ii. Ebongue, Egbe, Halle, Nida, Boten, Tocki read and corrected the manuscript

iii. Foumane and Adiogo supervised the writing of the manuscript

iv. Mboudou directed the study and validated the final version of the manuscript

\section{Thanks}

The authors thank the management of research hospitals and their staff for the support and facilities which have been granted to them for the realization of this research work.

\section{Acknowledgments}

None.

\section{Funding}

None.

\section{Conflicts of interest}

All authors declare that they have no competing interests.

\section{References}

1. Aly Abbara. The vagina - anatomical-physiological and pathological description. Paris: Aly Abbara; 2000.

2. Lepargneur JP, Rousseau V. Protective role of Doderleïn flora. Journal de Gynécologie Obstétrique et Biologie de la Reproduction. 2002;31(5):485-494.

3. Ravel J, Gajer P, Abdo Z, et al. Vaginal microbiome of reproductiveage women. Proc Natl Acad Sci U S A. 2011;108(1):4680-4687.

4. Sweet RL. Gynecologie conditions and bacterial vaginosis: implications for the non pregnant patient. Infect Ois Obstet Gynecol. 2000;8(3-4):184-190.

5. Schmid GP. The epidemiology of bacterial vaginosis. Int J Gynaecol Obstet. 1999;67:17-20.

6. Mayaud P. Tackling bacterial vaginosis and HIV in developing countries. Lancet. 1997;350:530-531.

7. Taha TE, Gray HR, Kummenda NI, et al. HIV infection and disturbances of vaginal flora during pregnancy. $J$ AIDS. 1999;20:52-59.

8. Bohbot JM, Lepargneur JP. Vaginosis in 2011: still a lot of questions. Gynecologie Obstétrique et Fertilité. 2012;40(1):31-36.

9. Wanderley S, Carlos R, Marcelo J, et al. Bacterial vaginosis in postmenopausal and infertile women. Bras Gynecol Obstet. 2011;23(10):641-646.

10. Faye K, Silla K, Cisse A, et al. Epidemiological and clinical aspects of bacterial vaginosis in Abidjan. Méd Afr Noire. 1992;39(9):607-609.

11. Holzam C, Leventhal JM, Qiu H, et al. Factor linked to bacterial vaginosis in nonpregnant women. Am $J$ Public Health Oct. 2011;91(10):1664-1670.

12. Silla K, Sow D, Lakhe NA, et al. Vulvovaginal candidiasis in the parasitology-mycology laboratory of the Fann University Hospital Center. Cames Santé. 2017;5(2):89-95.

13. Mardh JM, Mesnard R, Avril JL. Contribution of gram staining to the diagnosis of bacterial vaginosis by a standardized and reproducible reading method. Technique et Biologie. 1992;1:13-16.

14. Oshida K, Yanikkerem E, Yasayan A. Vaginal douching pratice: Frequency, associated factors and and relationship vulvovaginal symptoms. J Pak Med Assoc. 2006;66(44):387-392.

15. Juliano M, brotman RM, Klebanoff MA, et al. A longitudonal study of vaginal douching and bacterial vaginosis-a marginal structural modeling analysis. Am J Epidemiol Juil. 2008;168(2):188-196. 
16. Goswami R. et al. Species- specific Prevalence of vaginal candidiasis among patients with DiabetiesMelitus and relation to their glyceamic status. Journal of infection. 2000;41(2):162-166.

17. Lamont RF, Sobel JD, Akins RA, et al. The vaginal microbiome: new information about genital tract flora using molecular based techniques. An international Journal of Obstetrics and Genaecology. 2011;118(5):533-549.

18. Lepargneur JP. Lactobacillus crispatus, biomarker of the healthy vaginal ecosystem. Ann Biol Clin. 2016;74(4):421-427.
19. Lepargneur JP, Rousseau V. Protective role of Doderleïn flora Journal de Gynécologie Obstétrique et Biologie de la Reproduction. 2002;31(5):485-494.

20. Superbeck RR, Arvidson CG. Lactobacilli at the front line of depense against vaginally acquired infection. Future Microbiology. 2011;6(5):567-582. 